\title{
Effects of the Booroola Fec gene on ovarian follicular populations in superovulated Romanov ewes pretreated with a GnRH antagonist
}

\author{
J. J. Dufour ${ }^{1}$, Y. Cognié2 ${ }^{2}$ P. Mermillod ${ }^{2}$, J-C. Mariana ${ }^{2}$ and R. F. Romain ${ }^{3}$ \\ ${ }^{1}$ Département des sciences animales, Faculté des sciences de l'agriculture et de l'alimentation, Cité Universitaire, Sainte-Foy, (Québec), \\ Canada G1K 7P4; ${ }^{2}$ Physiologie de la Reproduction des Mammiferes Domestiques, Institut National Recherche Agronomique, 37380 \\ Nouzilly, France; and ${ }^{3}$ Centre de Recherche en Économie Agroalimentaire, FSAA, Université Laval, Sainte-Foy, Quebec, PQ, G1K 7P4, \\ Canada
}

\begin{abstract}
Endocrine control of follicular growth was studied in mature Romanov ewes carrying $(\mathrm{RF}+)$ or not carrying $(\mathrm{R}++)$ the Booroola $\mathrm{Fec}$ gene during an oestrous cycle after gonadotrophin-dependent follicles were suppressed by treatment with an antagonist of GnRH (Antarelix, $0.5 \mathrm{mg}$ per day) and superovulatory treatment was administered. The left ovary was removed after 10 days of treatment (saline or Antarelix) and the right ovary was removed at the end of the superovulatory treatment. Ewes of both genotypes treated with Antarelix had lower plasma LH concentrations than did controls from day 0 to day 10. The inhibitory effect of Antarelix on LH concentration increased with day of treatment. The variability in FSH concentrations during the initial 10 days was reduced by Antarelix treatment in both genotypes. Plasma FSH concentrations were higher in $\mathrm{RF}+$ ewes than in $\mathrm{R}++$ ewes. In both genotypes, FSH concentrations varied significantly with day of treatment, with the lowest concentrations at day 8 and the highest concentrations at day $5 . \mathrm{RF}+$ ewes had a greater total and atretic number of antral follicles $0.62-1.12,1.12-2.00$ and $2.00-3.00 \mathrm{~mm}$ in diameter (classes 2, 3 and 4) than did $\mathrm{R}++$ ewes before and after superovulatory treatment. After superovulatory treatment, the total number of atretic and non-atretic follicles $>3.00 \mathrm{~mm}$ in diameter (class 5) increased in both genotypes. Superovulatory treatment also increased the number of total and atretic class 4 follicles in RF+ only. Conversely, superovulatory treatment decreased the mean number of class 3 follicles in both genotypes, while the number of atretic follicles was decreased only in $\mathrm{R}++$ ewes. Antarelix treatment significantly reduced the percentage of follicles $>2.00 \mathrm{~mm}$ in diameter in $\mathrm{RF}+$ but not in $\mathrm{R}++$ ewes. Antarelix treatment before superovulatory treatment increased the total number of class 4 follicles in both genotypes but the increase was more significant in RF+ than in $\mathrm{R}++$ ewes. These results indicate that Antarelix pretreatment favours a greater superovulatory response in Romanov ewes carrying the $\mathrm{Fec}$ gene because ovulatory follicles are recruited from a wider range of follicular size classes.
\end{abstract}

\section{Introduction}

Attempts to control ovulatory response accurately after treatments with exogenous gonadotrophins have been unsuccessful in small ruminants. Among the various factors resulting in variation among breeds in cattle (Saumande et al., 1978), the FSH:LH ratio (Chupin et al., 1984) or the day of the cycle (Phillippo and Rowson, 1975), ovarian follicular features, such as size, number and state of atresia present at the time of treatment, have been proposed as important.

In sheep, an accumulation of antral follicles in the final stage of growth may allow an improvement in the superovulatory response. An increase in the number of follicles between 0.8 and $2.00 \mathrm{~mm}$ in diameter has been positively correlated with the PMSG-induced ovulation rate

Received 1 April 1999. in ewes (Driancourt, 1987). Therefore, treatment with a GnRH antagonist, allowing antral follicles to maintain their growth in the reserve pool by limiting gonadotrophin secretory activity, would be expected to standardize the ovulatory response of superovulated animals, as has been demonstrated by Cognié (1999).

Differences in ovarian function and in plasma concentrations of pituitary gonadotrophins associated with the $\mathrm{Fec}$ gene have been described in ovary-intact, ovariectomized and GnRH-treated hypothalamic-pituitary disconnected (HPD)-ovariectomized ewes (McNatty et al., 1991). No difference in the number of macroscopic follicles has been observed between the two Booroola genotypes in any previous study, and Fry et al. (1988) proposed that the difference in ovulation associated with the Fec gene is due to intraovarian factors. However, in this study, fewer than half 
of the hypophysectomized ewes ovulated after the PMSGhCG regimen, and concentrations of gonadotrophins over the treatment period were not determined to allow assessment of the completeness of hypophysectomy. The proposed intraovarian factors are observed in follicles selected for ovulation, and are known to differ in numbers between genotypes.

The purpose of this experiment was to investigate changes in the ovarian follicular population in response to a superovulatory treatment and to examine how this population is affected by the follicles present in the ovary in ewes carrying the Fec gene and pretreated with a GnRH antagonist.

\section{Materials and Methods}

\section{Experimental groups}

During the breeding season, mature crossbred Romanov $\times$ Booroola ewes were classified as heterozygous carriers (RF+) or non-carriers $(\mathrm{R}++)$ of the Fec gene on the basis of two previous annual ovulation rate $(\mathrm{OR})$ recordings of $>5$ (OR of $\mathrm{RF}+$ ewes $=6.9)$ or $<5(\mathrm{OR}$ of $\mathrm{R}++$ ewes $=4.1)$ as determined by laparoscopy. Oestrus was controlled using fluorogestone acetate-impregnated sponges (Chronogest; Intervet, Angers) inserted for 14 days (day 0 = day of insertion). On the day of sponge insertion, ewes were assigned to receive one of two treatments for 10 days to form the four following groups: (1) RF+ ewes with saline $(n=5) ;(2) \mathrm{RF}+$ ewes with anti-GnRH $(n=5)$; (3) R++ ewes with saline $(n=4)$; and (4) $\mathrm{R}++$ ewes with anti-GnRH $(n=4)$.

The GnRH antagonist (Antarelix; Europeptides, Argenteuil; $0.5 \mathrm{mg}$ per day) was injected subcutaneously once a day $(08: 00 \mathrm{~h})$. The dose and frequency of administration of the $\mathrm{GnRH}$ antagonist was shown to block final follicular development in Ile-de-France ewes in a preliminary study (Y. Cognié, unpublished). After treatment with the GnRH antagonist (saline for control) for 10 days, the left ovary was removed by laparotomy under general anaesthesia induced by barbiturates (i.v. injection of $0.5 \mathrm{~g}$ sodium thiopentone, Specia; Rhone Poulenc Rorer, Montrouge) and maintained by halothane in air. Purified pig FSH (pFSH, Ulg FMV Ph R. Liege) containing < $1 \mu \mathrm{g}$ LH per $150 \mu \mathrm{g}$ FSH was then injected i.m. twice a day (08:00 and 17:00 h) in decreasing doses over 3 days in saline-treated ewes (a total of $20 \mathrm{mg}$ from day 12 to day 14) or 4 days for Antarelix-treated ewes (a total of $36 \mathrm{mg}$ from day 11 to day 14 ).

The right ovary was removed at the end of the experiment, 12 and $24 \mathrm{~h}$ after the last pFSH injection and sponge removal, respectively, to determine the effect of a superovulatory hormonal treatment. The population of follicles was studied histologically.

\section{Hormone analyses}

Jugular blood samples were collected twice a day (08:00 and 17:00 h) immediately before GnRH antagonist administration from day 0 to day 10 . Plasma concentrations of FSH and LH were determined by radioimmunoassay in a single assay using a double antibody radioimmunoassay (Desaulniers et al., 1995).

Reagents for the LH assay included an ovine-LHantiserum (M. P. Dubois, INRA, Nouzilly) as the first antibody and oLH-1086 (Y, Combarnous, INRA, Nouzilly) as the tracer and standard. The sensitivity of the LH assay was $0.03 \mathrm{ng} \mathrm{ml}^{-1}$ and the intra-assay coefficient of variation was $8 \%$.

Reagents for the FSH assay were bovine $\mathrm{FSH}$ as the iodinated tracer (USDA-bFSH-1-2), bovine FSH (USDAbFSH-1-2) as the cold standard, and rabbit anti-ovine FSH (NIDDK-anti-oFSH-1) as the first antibody. The sensitivity of the assay was $0.04 \mathrm{ng} \mathrm{ml}^{-1}$, and the intra-assay coefficient of variation was $7 \%$. Sheep anti-rabbit gammaglobulin was used as a precipitating second antibody for both LH and FSH assays.

Concentrations of $\mathrm{LH}$ and FSH were determined for each blood sample (day 0 to day 10) collected twice a day. In the LH assay, the software program (Four Parameter Logistic; Iso-Data software, ICN Biomedical Inc., Micromedic Systems) assigned a value of $0.03 \mathrm{ng} \mathrm{ml}^{-1}$ to samples with values below the level of sensitivity of the assay .

\section{Ovarian analyses}

Within 5 min of collection, ovaries were perfused with Bouin-Hollande fixative via the utero-ovarian artery, and then immersed in fixative for 15 days. After fixation, ovaries were embedded in paraffin wax and serially sectioned at a thickness of $7 \mu \mathrm{m}$. Every fifth section was mounted, stained with haematoxylin, and observed. Antral follicles (>0.23 $\mathrm{mm}$ ) were counted, measured, and classified as atretic or non-atretic. A follicle was classified as atretic when five or more pycnotic bodies were observed bordering or within the granulosa cells of the section studied. All measurements were made on the section in which the oocyte was found, except for the largest follicles, for which measurements were recorded on the largest section limited by the basement membrane.

The area of each follicle was determined by using an electronic planimeter to trace around the basement membrane through a drawing tube fixed to the microscope. The diameter of the follicle $(\mathrm{mm})$ was calculated from the area $\left(\mu \mathrm{m}^{2}\right)$ by assuming that it was circular. Follicles were grouped into five size classes: class 1: $0.23-0.62 \mathrm{~mm}$; class 2: 0.63-1.12 mm; class 3: 1.13-2.00 mm; class 4: 2.01-3.00 mm; and class 5: $>3.00 \mathrm{~mm}$. The classification of antral follicles into five classes on the basis of size was made according to the criteria of Dufour et al. (1979). Follicles in the two largest classes $(>2.00 \mathrm{~mm}$ in diameter) are gonadotrophindependent, while those in the other three classes are not (Dufour et al., 1979).

\section{Statistical analysis}

Endocrine data. Data for FSH and LH were analysed by ANOVA using the General Linear Models (GLM) option of 
SAS/STAT (SAS, 1989). The effects of genotype, treatment, day, and time of day, as well as the two-way interactions between these effects were included in the statistical models used for analyses of hormone concentrations (Cody and Smith, 1997). The effects of day and time of day accounted for repeated measures on the same animal over time. The treatment effect in lowering the variability of $\mathrm{LH}$ and FSH concentrations was tested by Fisher's $F$ tests performed on the ratios of the variances of the treated groups (Antarelix) to those of the control groups.

Follicular data. The effect of treatment was tested statistically by an ANOVA using a split-plot model, the whole unit being ewes within treatment. The effect of FSH was tested within treatments, with the ewe within treatment as the subunit. The percentages of follicles $>2 \mathrm{~mm}$ (known to be gonadotrophin-dependent) before and after superovulatory treatment were compared using chi-squared analysis to determine the effects of Antarelix treatment.

\section{Results}

\section{LH and FSH hormone concentrations}

During the entire experimental period, ewes of both genotypes treated with Antarelix had lower plasma LH concentrations than did controls $(0.16 \pm 0.004$ versus $0.25 \pm$ $\left.0.012 \mathrm{ng} \mathrm{ml}^{-1} ; \quad P<0.002\right)$. A significant interaction was observed between treatment $(\mathrm{GnRH}$ antagonist versus saline) and day (days $0-10)(P<0.03)$. In Antarelix-treated ewes, LH concentrations decreased from day 0 to day 10 $\left(0.20 \pm 0.02\right.$ to $0.14 \pm 0.14 \mathrm{ng} \mathrm{ml}^{-1}$, respectively) but were maintained in control ewes $\left(0.21 \pm 0.02\right.$ to $0.23 \pm 0.04 \mathrm{ng} \mathrm{ml}^{-1}$, respectively) $(P<0.03$; Fig. 1$)$. In saline-treated ewes, $\mathrm{LH}$ concentrations were higher at the evening than at the morning sampling times $(0.27 \pm 0.02$ versus $0.21 \pm 0.01 \mathrm{ng}$ $\mathrm{ml}^{-1}$ ) while, in Antarelix-treated ewes, LH concentrations were similar at both times $\left(0.15 \pm 0.01\right.$ and $0.17 \pm 0.01 \mathrm{ng} \mathrm{ml}^{-1}$ for evening and morning sampling times, respectively; treatment $\times$ time: $P<0.005$ ). Plasma LH concentrations were not significantly different between the two genotypes $(P>0.10)$.

The FSH response to Antarelix differed in terms of variability, but not in terms of concentration when compared with that in the control ewes. Indeed, a comparison of variances of plasma FSH concentrations in Antarelix- and saline-treated ewes showed that the variability in $\mathrm{FSH}$ concentration was reduced by Antarelix treatment $(P<$ 0.001). In addition, the variability in plasma FSH concentration in Antarelix-treated ewes was greater in the $\mathrm{RF}+$ group than in the $\mathrm{R}++$ group $(P<0.001)$. Plasma FSH concentrations were higher in ewes carrying the $\mathrm{Fec}$ gene than in ewes not carrying the gene (Fig. 2, $1.31 \pm 0.05$ versus $\left.0.92 \pm 0.03 \mathrm{ng} \mathrm{ml}^{-1} ; P<0.002\right)$. In $\mathrm{RF}^{+}$, the FSH concentrations were higher at the evening than at the morning sampling times $\left(1.45 \pm 0.08\right.$ versus $\left.1.17 \pm 0.04 \mathrm{ng} \mathrm{ml}^{-1}\right)$ while, in $\mathrm{R}^{++}$ ewes, the FSH concentrations were similar at both sampling times $\left(0.90 \pm 0.04\right.$ and $0.95 \pm 0.05 \mathrm{ng} \mathrm{ml}^{-1}$ at evening and morning sampling times, respectively; genotype $\times$ time:
$P<0.01)$. In both genotypes, FSH concentrations reached peak values on day $5\left(1.39 \pm 0.2 \mathrm{ng} \mathrm{ml}^{-1}\right)$ and decreased to $0.91 \pm 0.07 \mathrm{ng} \mathrm{ml}^{-1}$ on day $8(P<0.001)$.

\section{Overall population of antral follicles}

Genotype and the effects of superovulatory treatment. The effects of genotype and superovulatory treatment on the numbers of antral follicles grouped into five size classes are shown (Fig. 3). The Antarelix treatment is ignored in these analyses because it was not significant, either as a main effect or in interaction with genotype and superovulatory treatment.

The mean total number and the number of atretic follicles in size classes 2, 3 and 4 were significantly greater in RF+ ewes than in $\mathrm{R}++$ ewes $(P<0.05$; Fig. $3 \mathrm{a}, \mathrm{b})$. For non-atretic follicles, only those in size classes 2 and 3 were more numerous in $\mathrm{RF}+$ ewes $(P<0.05$ and $P<0.0009$, respectively) (Fig. 3c). Superovulatory treatment increased the mean total number of follicles in size classes 4 and 5 in RF+ ewes, but only those in size class 5 in $\mathrm{R}++$ ewes (Fig. 3a; genotype $\times$ superovulatory treatment interaction for class 4 : $P<0.08$; and before versus after superovulatory treatment in both genotypes for class 5: $P<0.0009)$. Superovulatory treatment significantly increased the mean number of atretic and non-atretic class 5 follicles in both genotypes $(P<0.0009$ and $P<0.004$, respectively) (Fig. 3b,c). Superovulatory treatment significantly decreased the mean number of atretic follicles in size classes 2 and 3 in $\mathrm{R}++$ ewes, but only those of size class 2 in RF+ ewes (Fig. 3b) (superovulatory treatment for class 2: $P<0.01$; genotype $\times$ superovulatory treatment interaction for class 3 : $P<0.08$ ). Superovulatory treatment significantly decreased the mean total number $(P<0.08)$ and the number of non-atretic follicles $(P<0.01)$ in size class 3 in both genotypes (Fig. 3b).

Effects of Antarelix and genotype. When antral follicles were grouped into two size classes (gonadotrophin-dependent or gonadotrophin-independent: $>2.00 \mathrm{~mm}$ or $<2.00 \mathrm{~mm}$ in diameter, respectively: Fig. 4), and when the ovarian response was analysed using the difference between ovaries (before and after superovulatory treatment) with five size classes (Figure 5), both genotype and Antarelix treatments were found to have statistically significant effects on ovarian response.

Before superovulatory treatment, Antarelix decreased the proportion of total follicles $>2 \mathrm{~mm}$ in RF+ ewes, but not in R++ ewes (Fig. 4a; $P<0.05$ ). However, after superovulatory treatment, Antarelix increased the percentage of total follicles $>2.00 \mathrm{~mm}$ only in $\mathrm{R}++$ ewes (Fig. $4 \mathrm{a} ; P<0.001$ ). In RF+ ewes, Antarelix treatment increased the proportion of atretic follicles $>2.00 \mathrm{~mm}$ after superovulatory treatment and decreased the proportion $<2.00 \mathrm{~mm}$ (Fig. 4b,c; $P<0.0001$ ).

Changes in the numbers of follicles in the five size classes in ovaries of the same animal before and after superovulatory treatment were studied by ANOVA $(2 \times 2$ factorial). The number of class 1 follicles (both atretic and non-atretic) was reduced by superovulatory treatment, but only in $\mathrm{R}++$ ewes treated with Antarelix (Fig. 5a,b; 


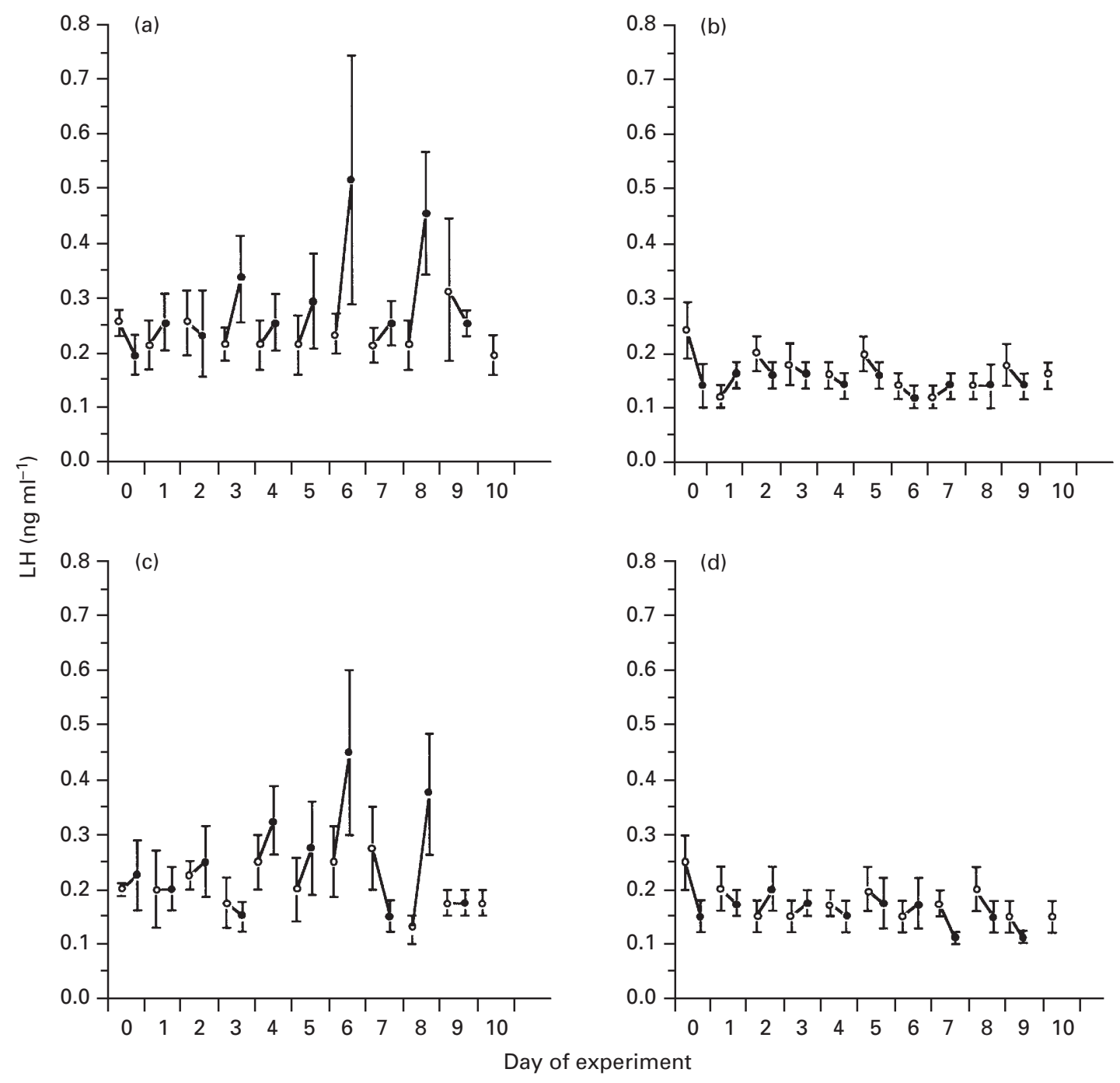

Fig. 1. LH concentrations in ewes with $(\mathrm{RF}+; \mathrm{a}, \mathrm{b})$ and without $(\mathrm{R}++; \mathrm{c}, \mathrm{d})$ the Booroola Fec gene treated with saline $(\mathrm{a}, \mathrm{c})$ or $\mathrm{GnRH}$ antagonist $(\mathrm{b}, \mathrm{d})$ at the morning $(O)$ and evening $(\bullet)$ sampling times. Statistical comparisons: treatment (GnRH antagonist versus saline): $P<0.003$; treatment (GnRH antagonist versus saline) $\times$ day (days $0-11): P<0.03$; treatment (GnRH antagonist versus saline) $\times$ sampling time (morning versus evening): $P<0.0005$.

interaction between genotype and Antarelix; $P<0.08)$. The decrease after superovulatory treatment in the number of non-atretic follicles in size class 3 was greater in $\mathrm{RF}+$ than in $\mathrm{R}++$ ewes (Fig. $5 \mathrm{~b} ; \mathrm{P}<0.08$ ). The change in the number of atretic class 3 follicles after superovulatory treatment was greater in RF+ ewes than in $\mathrm{R}++$ ewes (Fig. 5c; $P<0.08$ ). The difference in the total number of class 4 follicles before and after superovulatory treatment was greater for RF+ ewes than for $\mathrm{R}++$ ewes and was increased by Antarelix treatment in both genotypes (Fig. 5a; $R F+$ versus $R++: ~ P<0.08$; Antarelix versus saline: $P<0.08)$.

\section{Discussion}

The results of the present study indicate that the Booroola gene acts directly on the ovaries by modulating follicular development, allowing twice as many follicles to develop in the reserve pool $(0.23-2.00 \mathrm{~mm}$ in diameter) from where ovulatory follicles are recruited. The results also indicate that Romanov ewes carrying the Fec gene have a higher selection rate, since atresia is much higher among recruited follicles, thereby limiting the number of follicles proceeding to ovulation. In contrast, in ewes not carrying the Fec gene, the selection process is much less severe in terms of atresia, sparing the recruitable follicles in the reserve pool and allowing them to proceed to ovulation. Therefore, the process of follicular development leading to a higher ovulation rate in ewes carrying the $\mathrm{Fec}$ gene is wasteful because a larger number of recruited follicles become atretic after superovulatory treatment.

This difference in follicular development associated with the Fec gene has not been observed previously by measuring macroscopic follicles, possibly due to differences among the breeds studied, the techniques used, or both. In the present study, the effects of the Fec gene were studied histologically 


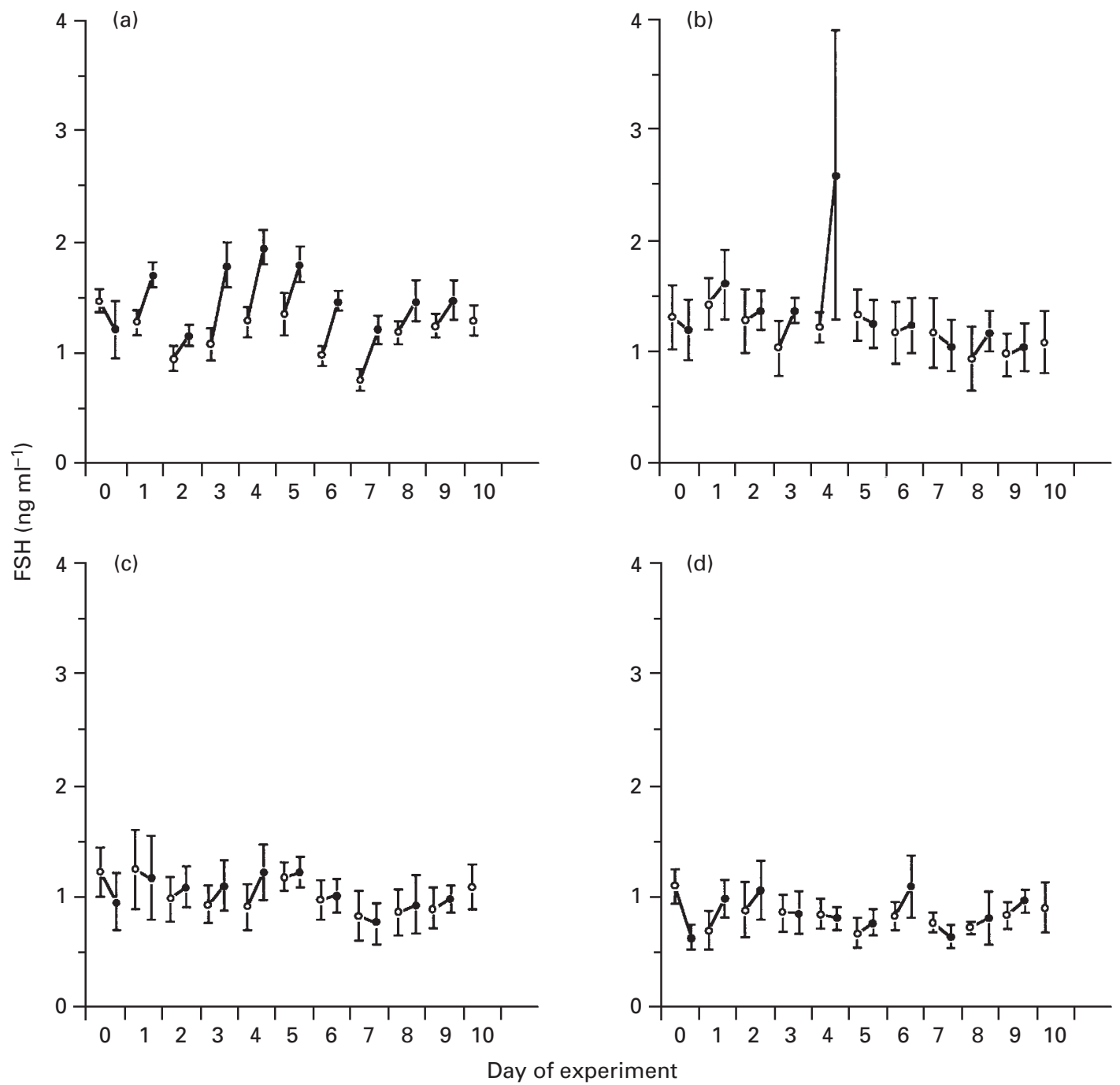

Fig. 2. FSH concentrations in ewes with $(\mathrm{RF}+; \mathrm{a}, \mathrm{b})$ and without $(\mathrm{R}++; \mathrm{c}, \mathrm{d})$ the Booroola Fec gene treated with saline $(\mathrm{a}, \mathrm{c})$ or GnRH antagonist $(\mathrm{b}, \mathrm{d})$ at the morning $(\bigcirc)$ and evening $(-)$ sampling times. Statistical comparisons: genotype (RF+ versus $\mathrm{R}++$ ): $P<0.03$; day (days $0-11$ ): $P<0.001$; sampling time (morning versus evening): $P<0.0006$; genotype (RF+ versus $\mathrm{R}++) \times$ sampling time (morning versus evening): $P<0.01$.

in Romanov ewes, which are known to be a prolific breed while, in previous studies, only surface follicles were observed in non-prolific ewes. Histological study detects follicles in the ovarian stroma as well as those on the ovarian surface, allowing determination of whether a follicle undergoes growth or atresia. Dufour et al. (1999) observed important differences in the number and size distribution of follicles in 3-month-old calves, but only when histological techniques were used. These differences were not detected by ultrasonography (Dufour et al., 1999). The difference in ovarian follicular development observed between RF+ and $\mathrm{R}++$ ewes treated with saline appears to be associated with basal LH and FSH secretory activities.

Mean serum concentrations of LH measured in Antarelixtreated ewes were different from those in saline-treated ewes, confirming that Antarelix injected once a day inhibited gonadotrophin secretory activities (Oussaid et al., 1999). This effect of Antarelix treatment on LH response differed from that of FSH, in that Antarelix decreased LH concentrations from the first day of treatment in both genotypes, while it decreased the variability, but not the concentration, of FSH. The difference in FSH variability between $\mathrm{RF}+$ and $\mathrm{R}++$ ewes, still observed after a 10 day Antarelix treatment in the present study, may be due to prolonged treatment limiting FSH secretory activity in RF+ ewes, as has been shown by Hudson et al., (1999). Hudson et al. (1999) also reported that differences in FSH concentrations between homozygous carriers and non-carriers of the Booroola Fec gene before treatment were not seen after 3 weeks of treatment with a GnRH antagonist. Hudson et al. (1999) reported similar differences in FSH and LH secretion patterns between RF+ and $\mathrm{R}++$ saline-treated ewes to those reported here. McNeilly and Fraser (1987) have shown that, during infusion of a GnRH agonist in sheep, the decrease in LH occurs earlier 

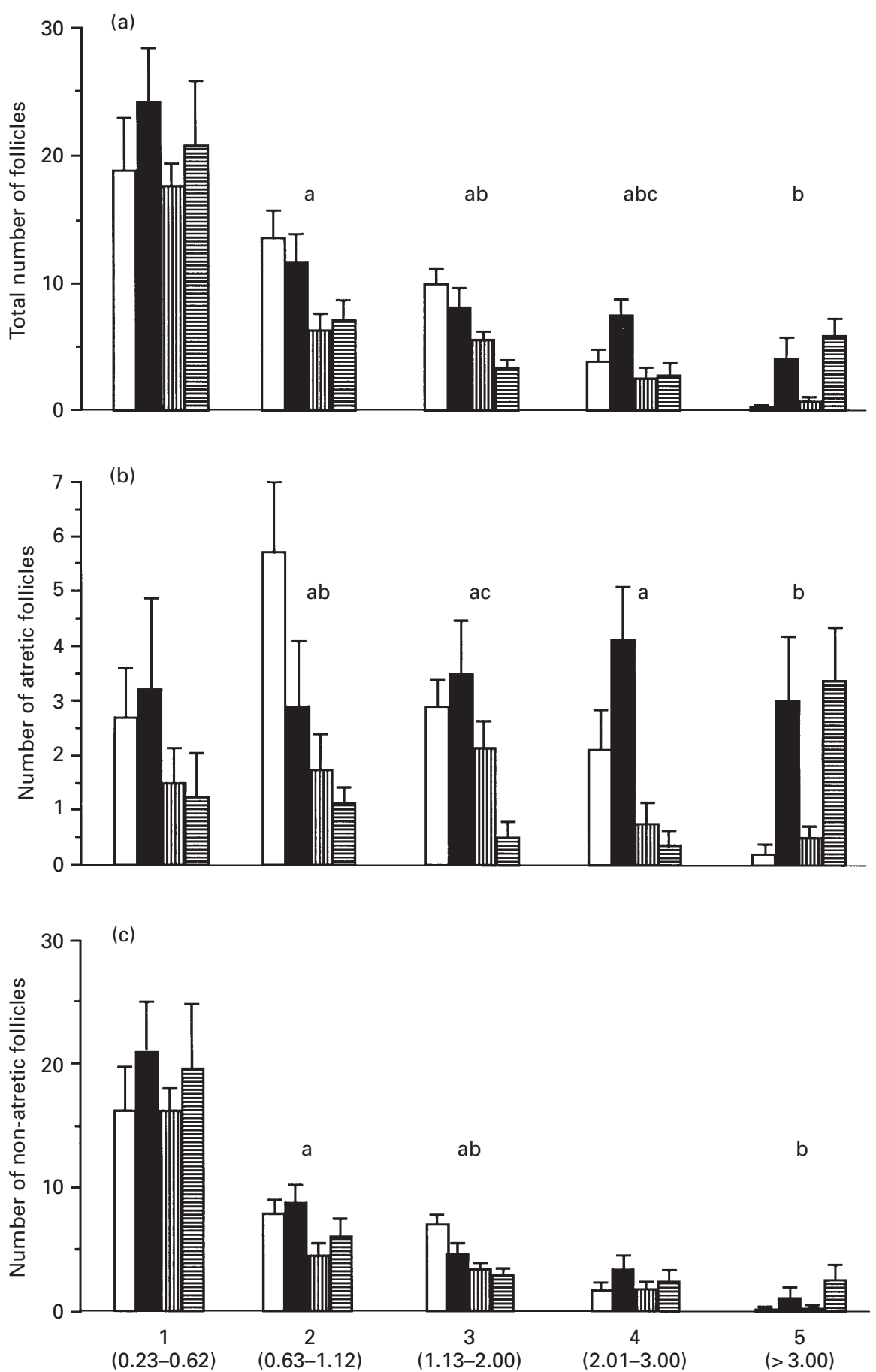

Class and diameter of follicles $(\mathrm{mm})$

Fig. 3. Total (a), atretic (b) and non-atretic (c) numbers of follicles in size classes 1-5 in ewes with (RF+) and without (R++) the Booroola Fec gene before superovulatory treatment and after a 3 day superovulatory treatment. $\square, R F+$ before superovulatory treatment; $\mathbf{\square}, \mathrm{RF}+$ after superovulatory treatment; 四, $\mathrm{R}++$ before superovulatory treatment; 目, $\mathrm{R}++$ after superovulatory treatment. Antarelix treatment was disregarded in this analysis because no statistical differences were observed. Statistical significance is represented by superscripts: agenotypes, ${ }^{\mathrm{b}}$ superovulatory treatment, and cinteractions as indicated below for each variable. Statistical comparisons: (a) total number of follicles: class 2 , genotype $(P<0.03)$; class 3 , genotype $(P<0.001)$ and superovulatory treatment $(P<0.08)$; class 4 , genotype $(P<0.003)$, superovulatory treatment $(P<0.04)$ and genotype $\times$ superovulatory treatment interaction $(P<0.08)$; class 5 , superovulatory treatment $(P<0.0009)$. $(\mathrm{b})$ Atretic follicles: class 2 , genotype $(P<0.04)$ and superovulatory treatment $(P<0.01)$; class 3 , genotype $(P<0.01)$ and genotype $\times$ superovulatory treatment interaction $(P<0.08)$; class 4 , genotype $(P<0.0002)$; class 5 , superovulatory treatment $(P<0.004)$. (c) Non-atretic follicles: class 2 , genotype $(P<0.05)$; class 3 , genotype $(P<0.0009)$ and superovulatory treatment $(P<0.01)$; class 5 , superovulatory treatment $(P<0.0009)$. 

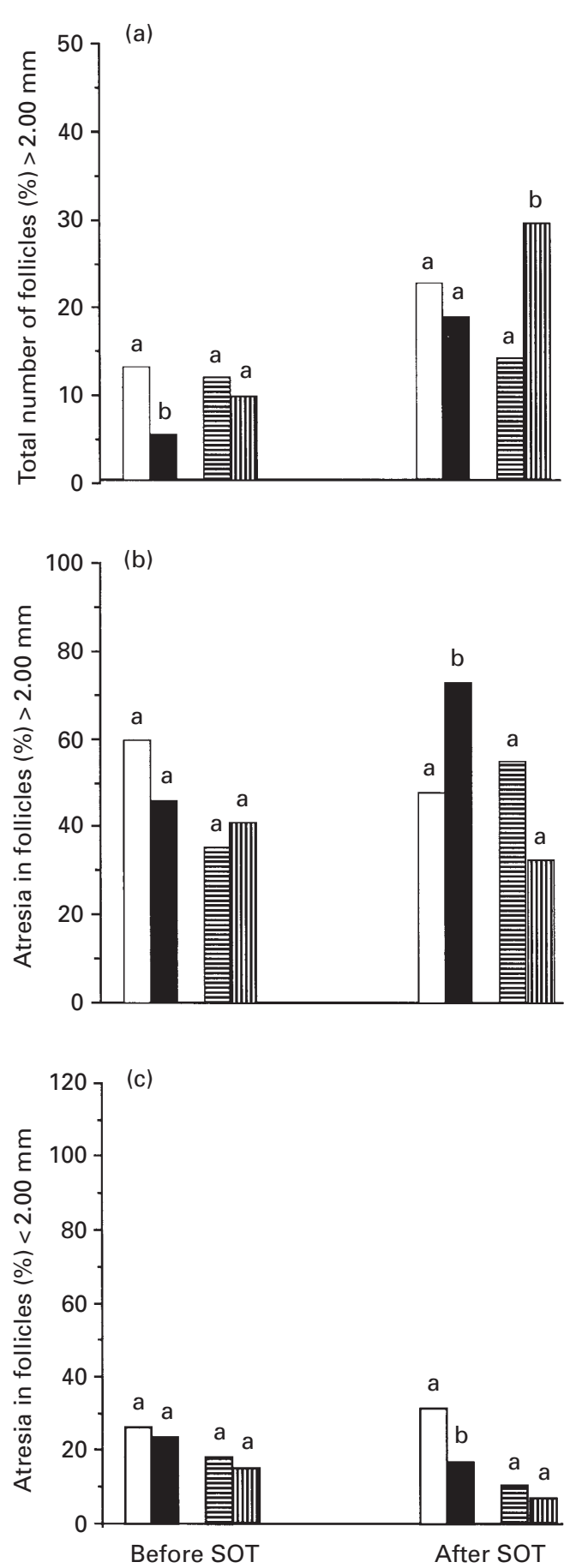

Fig. 4. Distribution of (a) the total number and $(b, c)$ number of atretic follicles $>2 \mathrm{~mm}(\mathrm{a}, \mathrm{b})$ or $<2 \mathrm{~mm}$ (c) before and after $\mathrm{pFSH}$ superovulatory treatments in ewes with $(\mathrm{RF}+)$ and without $(\mathrm{R}++)$ the Booroola $\mathrm{Fec}$ gene, treated with saline or $\mathrm{GnRH}$ antagonist (Antarelix). $\square, \mathrm{RF}+$, saline-treated; $\mathbf{\square}, \mathrm{RF}+$, Antarelix-treated; 目, $\mathrm{R}++$, saline-treated; 四, R++, Antarelix-treated. Statistical comparisons: (a) Total numbers of follicles $>2.00 \mathrm{~mm}$, before superovulatory treatment: Antarelix treatment significantly decreased the percentage of follicles $>2.00 \mathrm{~mm}$ but only in RF+ ewes; chi-squared $=7.7$ and 0.5 , respectively, for RF+ and R++ ewes. Total numbers of follicles $>2.00 \mathrm{~mm}$, after superovulatory treatment: Antarelix treatment significantly increased the percentage than the decrease in FSH. Campbell et al. (1998) showed that $\mathrm{FSH}$ and LH concentrations, measured every 4 days, were lowered by a 3 week GnRH antagonist treatment in ewes with ovarian autotransplants.

Antarelix was used to limit gonadotrophin secretory activity and to stop gonadotrophin-dependent follicles from pursuing their follicular development to the final stage. This effect of Antarelix allowed follicles to accumulate in the medium size pool, which could increase and homogenize the ovulatory response after superovulatory treatment in both genotypes. When follicular development was followed by observing the proportion of follicles $>2 \mathrm{~mm}$ in diameter, Antarelix treatment did allow follicles to accumulate in size classes $<2 \mathrm{~mm}$, but only in $\mathrm{RF}+$ ewes, resulting in a reserve pool of ovarian follicles from which growing follicles could be recruited. This effect was not observed in $\mathrm{R}++$ ewes, which exhibited lower antral follicle development at the end of treatment with Antarelix than did RF+ ewes. McNeilly and Fraser (1987) have shown that infusion of GnRH agonist blocks the final follicular development, as indicated by the absence of oestrus and, presumably, ovulation. It should be noted that the GnRH agonist was infused for 3 weeks in this study and that the microscopic follicular population was not observed (McNeilly and Fraser, 1987). Campbell et al. (1998) reported that macroscopic follicles $>3.00 \mathrm{~mm}$ were not found in non-prolific Leicester Merino crossbred ewes with ovarian autotransplants at the end of a 3 week GnRH antagonist treatment. However, no control data on macroscopic follicular development in untreated ewes or during the time course of GnRH antagonist treatment were reported (Campbell et al., 1998).

Exogenous pFSH treatment recruited follicles from the same size class in both $\mathrm{RF}+$ and $\mathrm{R}++$ ewes. Therefore, only one size class of follicles $(1.12-2.00 \mathrm{~mm})$ served as the reserve pool for recruitment of presumptive ovulatory follicles in both genotypes. In RF+ ewes, two size classes (2.00-3.00 mm and $>3.00 \mathrm{~mm}$ ) were increased in number after pFSH treatment while, in $\mathrm{R}^{++}$ewes, only follicles $>3.00 \mathrm{~mm}$ were increased. Therefore, as has been suggested by McNatty et al. (1986), these data indicate that follicles in Romanov ewes carrying the Fec gene reached maturity at a smaller diameter than those in ewes not carrying the gene. The higher ovulation rate observed in ewes carrying the Fec gene may be due to this difference in the size at which follicles are selected for ovulation, and because relatively more large follicles are present.

The left ovary of a ewe was used as a control for the right ovary after hormonal treatments to reduce the effect of variation between individuals. Whether ewes with one

of follicles $>2.00 \mathrm{~mm}$ but only in R++ ewes; chi-squared $=11.9$ and 2.0, respectively, for $\mathrm{R}++$ and $\mathrm{RF}+$ ewes. (b) Atretic follicles $>2.00$ $\mathrm{mm}$, after superovulatory treatment: Antarelix treatment significantly increased the percentage of atretic follicles $>2.00 \mathrm{~mm}$ but only in RF+ ewes; chi-squared $=6.6$ and 3.0, respectively, for RF+ and $\mathrm{R}++$ ewes. (c) Atretic follicles $<2.00 \mathrm{~mm}$, after superovulatory treatment: Antarelix treatment significantly decreased the percentage of follicles $<2.00 \mathrm{~mm}$ but only in RF+ ewes; chi-squared $=16.5$ and 0.5 respectively, for $R F+$ and $R++$ ewes. 
(a)

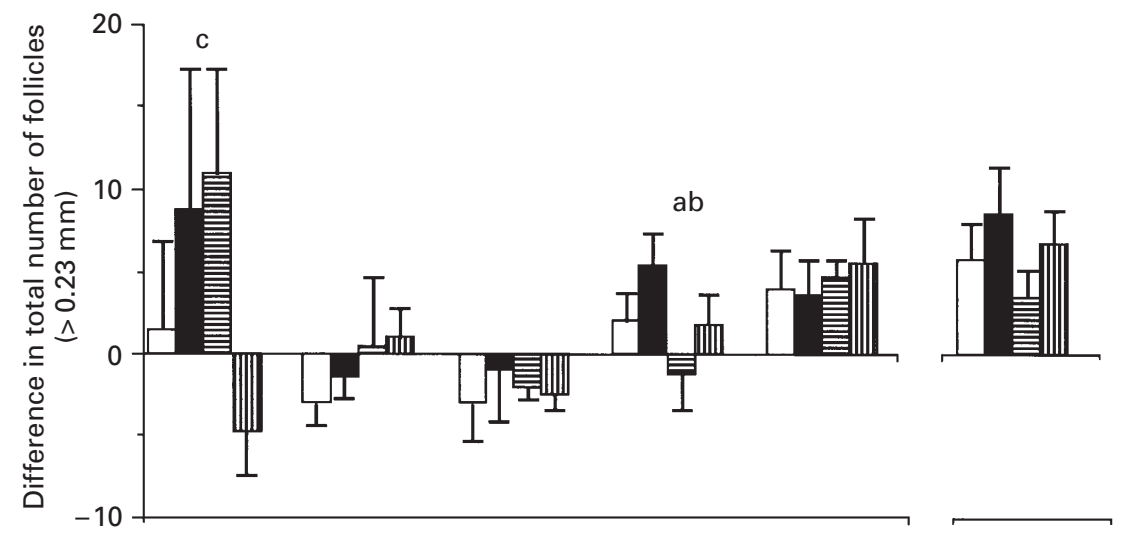

(b) $\mathrm{c}$

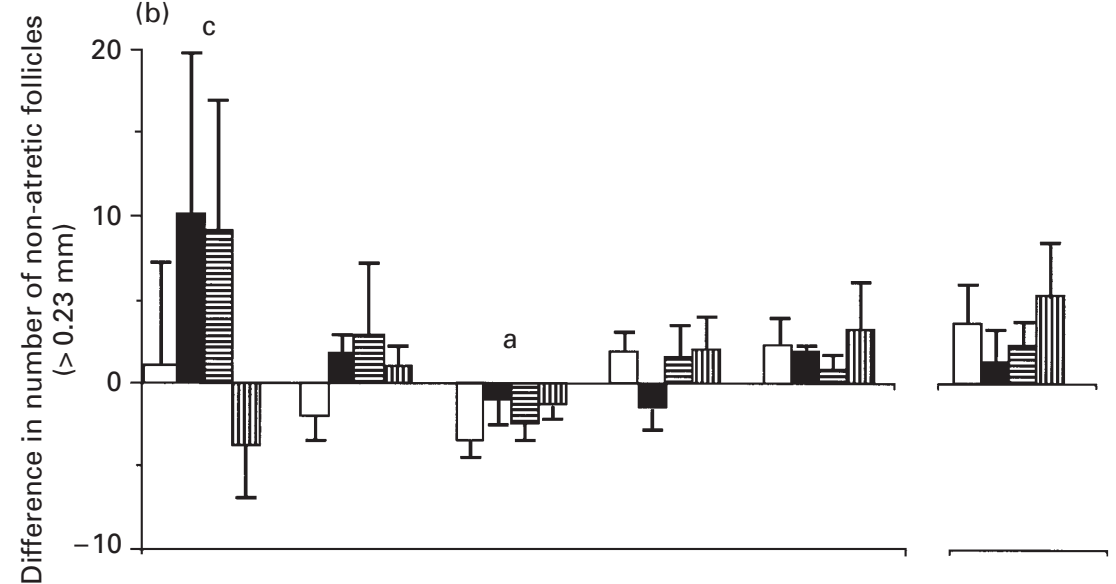

(c)

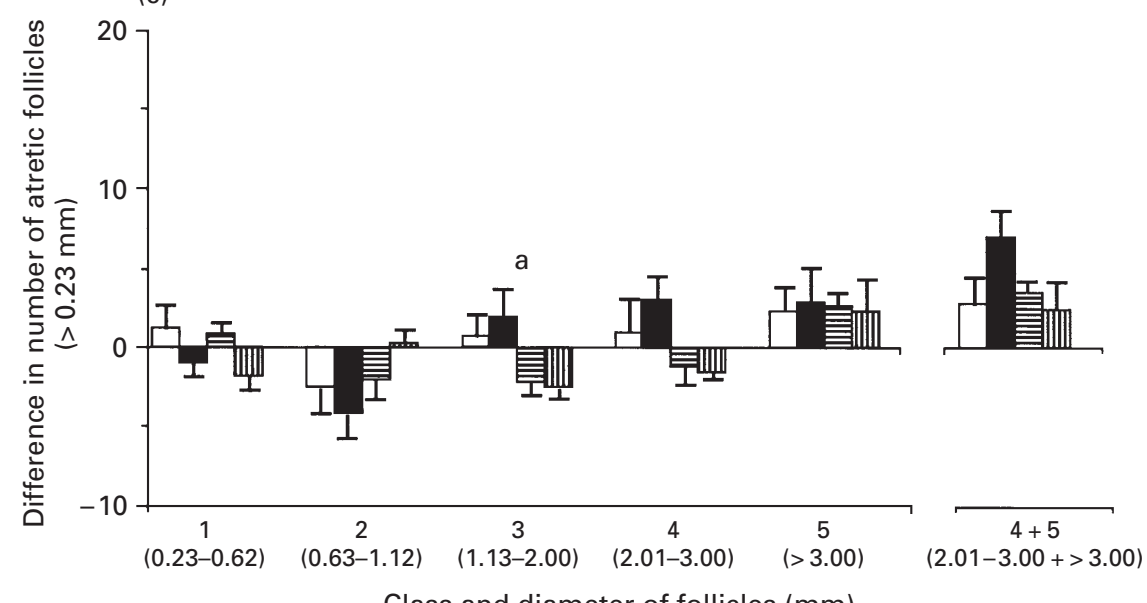

Class and diameter of follicles $(\mathrm{mm})$

Fig. 5. Differences in (a) the mean total, (b) non-atretic and (c) atretic antral follicles between the two ovaries of ewes with ( $\mathrm{RF}+$ ) and without $(\mathrm{R}++)$ the Booroola Fec gene treated with saline and GnRH antagonist before pFSH superovulatory treatment. $\square, \mathrm{RF}+$, saline-treated; $\mathbf{0}, \mathrm{RF}+$, Antarelix-treated; 目, R++, saline-treated; 皿, R++, Antarelixtreated. Statistical significance is represented by superscripts: agenotypes, ${ }^{\mathrm{b}}$ Antarelix, and cinteractions as indicated below for each variable. Statistical comparisons: (a) Total number of follicles: class 1, interaction between genotype and Antarelix $(P<0.09)$; class 4 , genotype $(P<0.08)$; class 4 , Antarelix $(P<0.09)$. (b) Non-atretic follicles: class 1 , interaction between genotype and Antarelix $(P<0.09)$; class 3 , genotype $(P<0.08)$. (c) Atretic follicles: class 3 , genotype $(P<0.08)$. 
ovary respond differently to hormonal treatments than ewes with two ovaries is not known, but similarity between the follicular populations of ovaries within sheep (Cahill et al., 1979) cattle (Dufour and Roy, 1985) and pigs (Simoneau et al., 1988), and the lack of a short-term effect of unilateral ovariectomy in sheep (Dufour and Guilbault, 1984) and cattle (Monniaux et al., 1983) indicate that this experimental approach is valid.

Antarelix treatment allowed a better follicular response after superovulatory treatment when determined by differences between the two ovaries of the same animal in $\mathrm{RF}+$ and $\mathrm{R}++$ ewes, with a greater response in $\mathrm{RF}+$ ewes. Similarly, in $\mathrm{R}++$, but not RF+ ewes, Antarelix facilitated a greater follicular response to superovulatory treatment, as determined by observing the proportion of follicles $>2 \mathrm{~mm}$. Superovulatory treatment after Antarelix treatment was accompanied by a decrease in the proportion of atretic follicles $>2 \mathrm{~mm}$ in $\mathrm{R}++$ ewes but an increase in the proportion of atretic follicles $>2 \mathrm{~mm}$ in $\mathrm{RF}+$ ewes.

The present results are in agreement with those of Hudson et al. (1999) who deprived homozygous Fec carriers and noncarriers of FSH by hypothalamic-pituitary disconnection (HPD) of ovary-intact or GnRH agonist-treated ewes. Hudson et al. (1999) showed that ovulation rates were not significantly different between the genotypes when given an identical regimen of $\mathrm{FSH}$, although some $40 \%$ of the treated ewes of both genotypes in this study failed to respond to the FSH regimen, and the ovulation rates were based only on those ewes that did ovulate. No explanation was offered for the low response to ovulatory treatment after hormonal deprivation (Hudson et al., 1999). Results from the present study indicate that the high rate of atresia observed in ewes carrying the $\mathrm{Fec}$ gene would leave too few non-atretic follicles for injected FSH to act on.

The pFSH superovulatory treatment was initiated 1 day earlier in Antarelix-treated ewes (day 11 versus day 12 for Antarelix- and saline-treated ewes) to allow available follicles to receive enough FSH to continue growing to higher size classes. The additional $16 \mathrm{mg}$ pFSH injected in Antarelix-treated ewes did not cause any significant difference in ovarian follicular response when compared with that in saline-treated control ewes. However, when the ovarian response was determined by comparing two ovaries from the same ewe (before versus after superovulatory treatment), Antarelix treatment allowed an increase in follicular development, with the response being different for $\mathrm{RF}+$ and $\mathrm{R}++$ ewes. This difference between genotypes treated with Antarelix was dependent on follicular size and the histological condition of the follicles. A difference in the FSH threshold among breeds and individuals may explain why it is difficult to control follicular development and ovulation rate accurately.

The decrease in mean circulating concentrations of LH-FSH after treatment indicates that Antarelix reduces the growth of antral follicles and allows them to accumulate in the reserve pool (from 0.23 to $2.00 \mathrm{~mm}$ in diameter) from which ovulatory follicles are recruited. The expected standardized ovulatory response after superovulatory treatment was possible because the recruitment process is more important in Antarelix-treated ewes and is related to the size of the reserve pool. Superovulatory treatment induced different rates of atresia among recruited follicles for the two genotypes: RF+ ewes had an increased rate of atresia after superovulatory treatment, while $\mathrm{R}++$ ewes had a reduced rate.

This research was supported in part by CORPAQ and FCAR (Québec) and EC/AIR Contact number 920232. The authors wish to thank J. F. Beckers (Ulg FMV, Liege, Belgium) for the gift of pFSH, Europeptides (Argenteuil, France) for the gift of Antarelix and F. Dupont, A. Thomas, C. Guénette, A. Locatelli, D. André, C. Gauthier, C. Martin, J. Bricault, F. Silversides and P. Rouillier for their contributions.

\section{References}

Cahill LP, Mariana J-C and Mauléon P (1979) Total ovarian follicular populations in ewes of high and low ovulation rate Journal of Reproduction and Fertility 55 27-36

Campbell BK, Dobson H and Scaramuzzi RJ (1998) Ovarian function in ewes made hypogonadal with GnRH antagonist and stimulated with FSH in the presence or absence of low amplitude LH pulses Journal of Endocrinology 156 213-222

Chupin D, Combarnous Y and Procureur R (1984) Antagonistic effect of LH on FSH induced superovulation in cattle Theriogenology 21 Abstract 229

Cody RP and Smith JK (1997) Applied Statistics and the SAS Programming Language Prentice-Hall, Toronto

Cognié Y (1999) State of the art in sheep-goat embryo transfer Theriogenology 51 106-116

Desaulniers DM, Lussier JG, Goff AK, Bousquet D and Guilbault LA (1995) Follicular development and reproductive endocrinology during a synchronized estrous cycle in heifers and mature cows displaying contrasting superovulatory responses Domestic Animal Endocrinology 12 117-131

Driancourt MA (1987) Ovarian features contributing to the variability of PMSG-induced ovulation rate in sheep Journal of Reproduction and Fertility $80207-212$

Dufour JJ and Guilbault LA (1984) Ovarian follicular population changes with the advance of the breeding season in intact and unilaterally ovariectomized ewes Journal of Reproduction and Fertility 70 363-368

Dufour JJ and Roy GL (1985) Distribution of ovarian follicular populations in the dairy cow within 35 days after parturition Journal of Reproduction and Fertility 73 229-235

Dufour JJ, Cahill LP and Mauléon P (1979) Short- and long-term effects of hypophysectomy and unilateral ovariectomy on ovarian follicular populations in sheep Journal of Reproduction and Fertility 57 301-309

Dufour JJ, Mermillod P, Mariana J-C and Romain RF (1999) The effect of a GnRH agonist on follicular dynamics and response to FSH stimulation in prepubertal calves Reproduction Nutrition Development 39 139-144

Fry RC, Clarke IJ, Cummins JT, Bindon BM, Piper LR and Cahill LP (1988) Induction of ovulation in chronically hypophysectomized Booroola ewes Journal of Reproduction and Fertility $82711-715$

Hudson NL, O'Connell AR, Shaw L, Clarke IJ and McNatty KP (1999) Effect of exogenous FSH on ovulation rate in homozygous carriers or noncarriers of the Booroola $\mathrm{FecB}$ gene after hypothalamic-pituitary disconnection or after treatment with a GnRH agonist Domestic Animal Endocrinology 16 69-80

McNatty KP, Lun S, Heath DA, Ball K, Smith P, Hudson NL, McDiarmid J, Gibb M and Henderson KM (1986) Differences in ovarian activity between Booroola $\times$ Merino ewes which were homozygous, heterozygous and noncarriers of a major gene influencing their ovulation rate Journal of Reproduction and Fertility 77 193-205

McNatty KP, Hudson NL, Shaw L, Condell LA, Ball K, Seah S-L and Clarke IJ (1991) GnRH-induced gonadotrophin secretion in ovariectomized Booroola ewes with hypothalamic-pituitary disconnection Journal of Reproduction and Fertility 91 583-592

McNeilly AS and Fraser HM (1987) Effect of GnRH agonist-induced suppression of LH and FSH on follicle growth and corpus luteum function in the ewe Journal of Endocrinology 115 273-282

Monniaux D, Chupin D and Saumande J (1983) Superovulatory responses of cattle Theriogenology 19 1955-1981 
Oussaid B, Mariana JC, Poulin N, Fontaine J, Lonergan P, Beckers JF and Cognié Y (1999) Reduction of the developmental competence of sheep oocytes by inhibition of LH pulses during the follicular phase with a $\mathrm{GnRH}$ antagonist Journal of Reproduction and Fertility 117 71-77

Phillippo M and Rowson LEA (1975) Prostaglandins and superovulation in the bovine Annales de Biologie Animale Biochimie Biophysique 15 233-240

SAS/STAT User's Guide (1989) Statistical Analysis System Institute, Cary, $\mathrm{NC}$
Saumande J, Chupin D, Mariana J-C, Ortavant R and Mauléon P (1978) Factors affecting the variability of ovulation rates after PMSG stimulation. In Control of Reproduction in the Cow pp 195-225 Ed. JM Sreenan. Martinus Nijhoff, The Hague

Simoneau C, Estrada R, Matton P and Dufour JJ (1988) Effects of litter size and light regimen imposed during lactation on ovarian follicular population at weaning in third-parity sows Journal of Animal Science 66 2606-2613 